Portland State University

PDXScholar

Fall 2018

\title{
Small Steps on the Long Journey to Equality: A \\ Timeline of Post-Legislation Civil Rights Struggles in Portland
}

Leanne Claire Serbulo

Portland State University, serbulo@pdx.edu

Follow this and additional works at: https://pdxscholar.library.pdx.edu/usp_fac

Part of the Public Policy Commons, Social Policy Commons, Urban Studies Commons, and the Urban Studies and Planning Commons

Let us know how access to this document benefits you.

\section{Citation Details}

Serbulo, L. 2018. Small Steps on the Long Journey to Equality: A Timeline of Post-Legislation Civil Rights Struggles in Portland. Oregon Historical Quarterly, 119:3, 376-399.

This Article is brought to you for free and open access. It has been accepted for inclusion in Urban Studies and Planning Faculty Publications and Presentations by an authorized administrator of PDXScholar. Please contact us if we can make this document more accessible: pdxscholar@pdx.edu. 
Small Steps on the Long Journey to Equality: A Timeline of Post-Legislation Civil Rights Struggles in Portland

by Leanne Serbulo

THIS TIMELINE BEGINS where Employment Practices Act barred Richard Rothstein's The Color of Law discrimination in hiring, promotion, ends - with the passage of landmark and working conditions, but civil rights civil rights legislation. Oregon's first legislation was simply the first step in statewide anti-discrimination legis- a long and unfinished journey toward lation was passed in 1949. The Fair equality.
The effectiveness of anti-discrimination legislation depends on robust implementation and enforcement. Without outside pressure, local governments did not aggressively pursue a dismantling of discriminatory policies. At times, the implementation and enforcement of civil rights legislation was spurred from above by federal mandates or more often from below by grassroots organizations. In Portland after the legislation was in place, the Metropolitan Human Relations Commission (MHRC) acted as an intermedi- ary among the city, federal agencies, and the community-based groups in many civil rights struggles.

The MHRC began as a mayoral advisory committee in 1949. Initially called the Intergroup Relations Commission (IGRC), the committee had ten members appointed by Mayor Dorothy McCullough Lee and helped push fo a measure barring discrimination in public accommodations. In 1966, the IGRC was awarded a professional staff person, and it became known as the Human Relations Commission (HRC). In

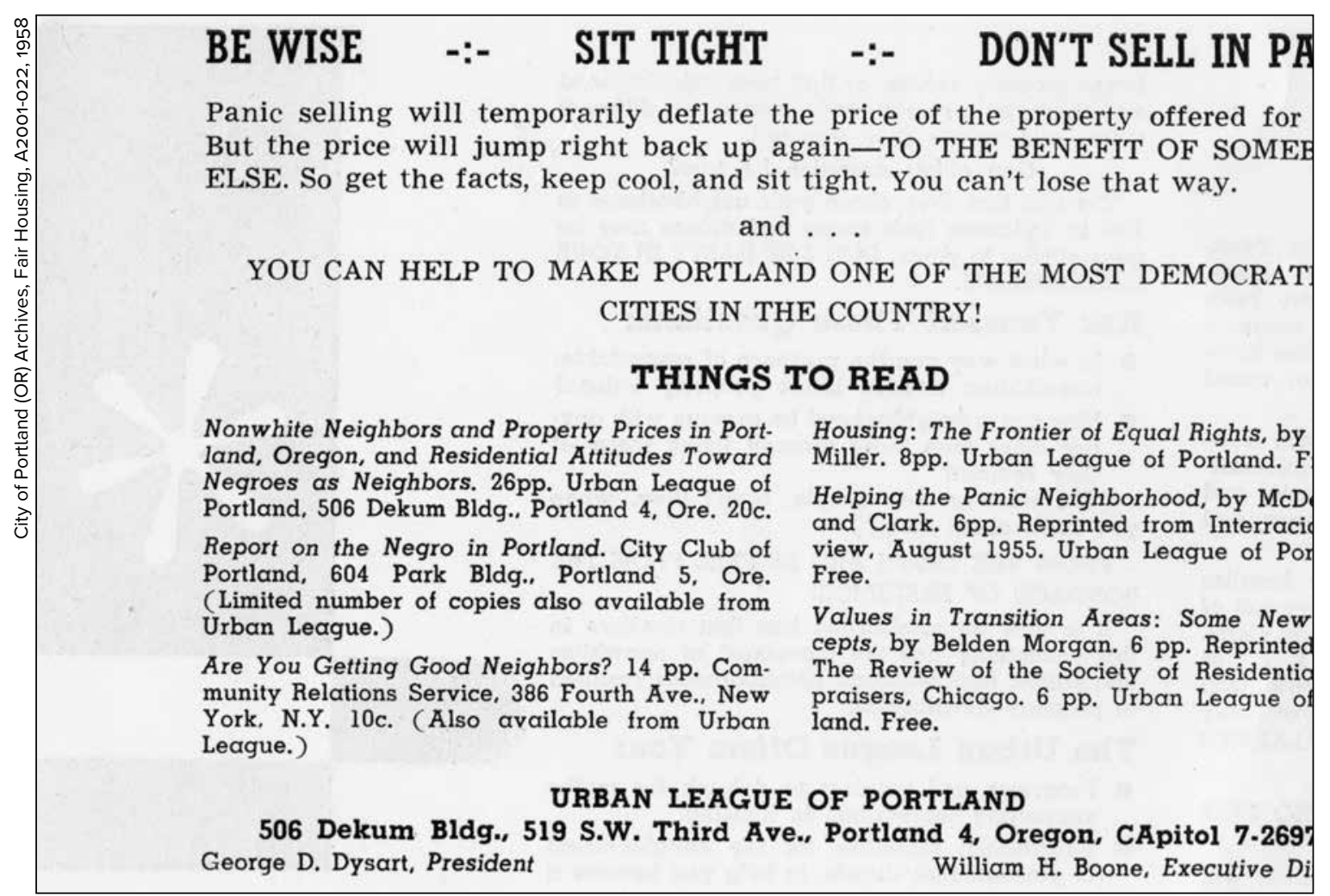

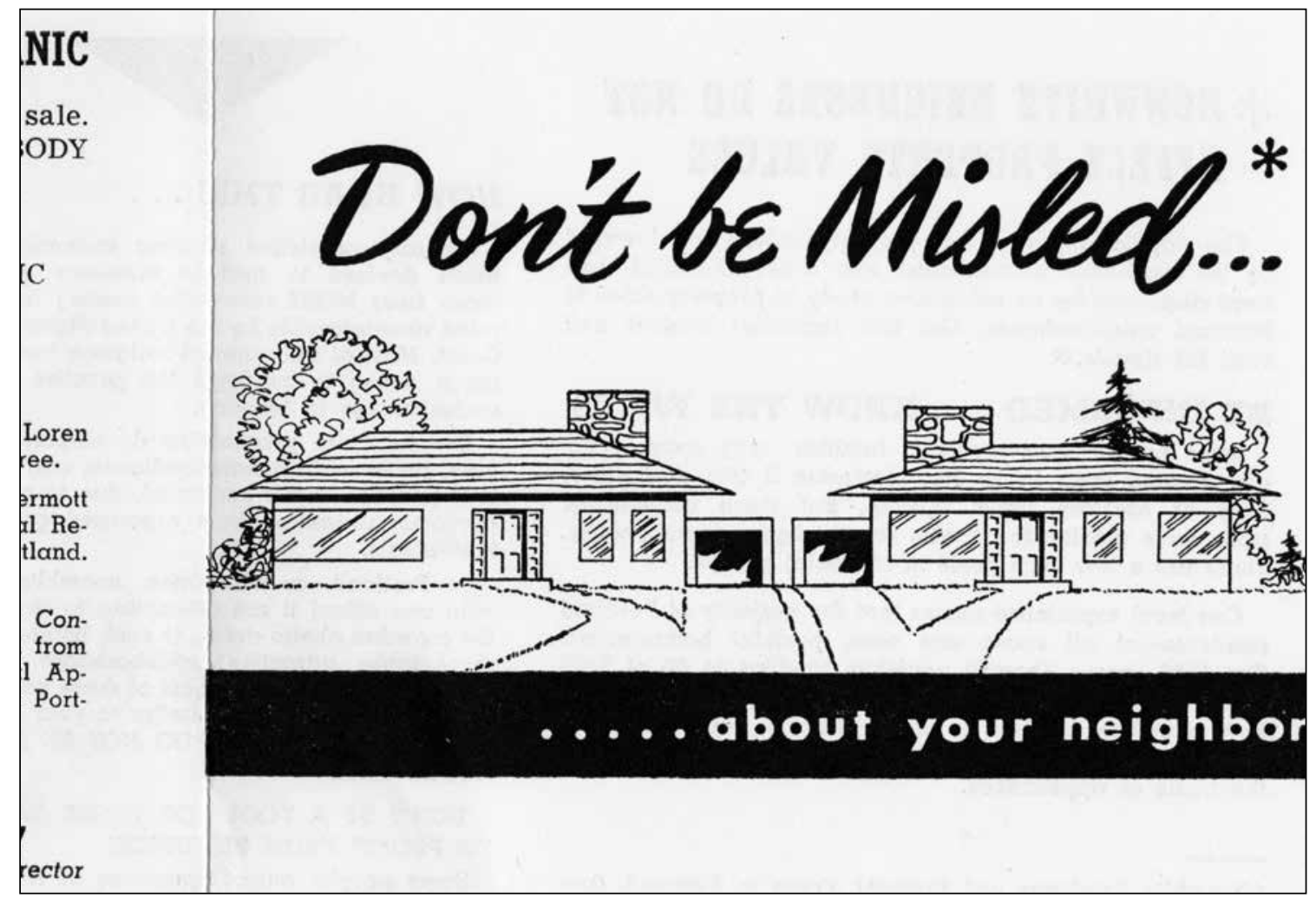

THE URBAN LEAGUE OF PORTLAND published this pamphlet titled "Don't be Misled" in 1958 in an attempt to curb white flight from neighborhoods. The pamphlet confronts myths that integrated neighborhoods reduce property values, and the Urban League advises homeowners to "be wise, sit tight, don't sell in panic." 
The MHRC kept one foot firmly within the community and another in the halls of power, but it was a delicate balance. In a 1968 memo, the HRC affirmed its role as an "advocate" for minority communities, not an "apologist" for the city. ${ }^{1}$ Still, commission members often felt "powerless" and recognized that much of their work would go "unpublicized," because they made "internal recommendations" to city agencies in an effort to avoid racial conflict in the streets.
Civil rights groups and the MHRC were most effective at changing public institutions. Dismantling racial discrimination in the private sector was a far bigger challenge. As a Housing and Urban Development (HUD) study on housing discrimination noted, "every routine, every bit of ritual in the sales or rental of a dwelling unit can be performed in a way and calculated to make it either difficult or impossible to consummate the deal."2 The MHRC and other civil rights organizations had little influence over the myriad of diffuse transactions in the housing market, and the public agencies that were empowered to regulate those markets were reluctant to aggressively police the private housing industry.

1949 The Oregon Legislature passes the Fair Employment Practices Act, barring discrimination due to race, religion, color, or national origin by employers with more than five workers or by labor unions. ${ }^{3}$ The bill passes the House on a 53-to-4 vote and the Senate by 27 -to-2. Oregon is the sixth state to pass an employment anti-discrimination bill.

1949 Mayor Dorothy McCullough Lee establishes an advisory committee on inter-group relations, after the Citizens' Committee for Civil Rights submits to City Council a proposed ordinance that would ban discrimination in public accommodations. ${ }^{4}$ The all-volunteer committee consists of ten men and women appointed by the mayor.

1950 The Portland City Council unanimously approves Ordinance 91214 prohibiting racial discrimination in public accommodations. ${ }^{5}$ The ordinance does not take effect immediately. After the vote, the city is recognized by the National Conference of Christians and Jews for its improvement in the area of race and religious relations.

The Civil Freedom Committee, an organization spearheaded by the Oregon Restaurant Association, which opposes the ordinance, collects enough signatures to refer the public accommodations ordi-

nance to voters. During the campaign, business owners in favor of the ordinance post signs in their windows stating "We Reserve the Right to Serve All Respectable Patrons," in an effort to counter and draw attention to the "Whites Only" placards that are displayed in some Portland businesses. Voters reject the measure by a vote of 77,084 to 60,969 , and discrimination in public accommodations remains legal. ${ }^{6}$

1953 The Oregon Legislature adopts a law banning discrimination due to race, color, national origin, or religion in the use of any public accommodation. ' While the initial bill would have made it a criminal offense to discriminate, the final version only allows for a civil penalty.

1958 The City Commission on Intergroup Relations and the Urban League organize a conference on housing discrimination at a Portland church. ${ }^{8}$ The governor, mayor, and representatives from the Home Builders Association, Federal Housing Authority, and Portland Realty Board speak alongside civil rights leaders. The Urban League publishes a pamphlet aimed at stopping block-busting and white flight, and confronting the pervasive myth that racial integration lowers property values. It encourages whites in the Portland metro area to "be wise, sit tight, and don't sell in panic," if a non-white neighbor moves in, and to instead, "know the truth and be free from the bondage of prejudice."

1959 The Oregon Legislature passes a fair housing law that prohibits discrimination in the "sale, rental or lease of private housing." Brokers who practice discrimination could lose their real estate license. During the hearings on the bill, the Urban League testifies that it is common practice for real estate agents to refrain from selling homes to Black families in white neighborhoods without first gaining consent from every white resident.

1960 The Albina Neighborhood Improvement Committee is established by a group of residents wanting to clean up their neighborhood and improve their homes..$^{10}$ This multiracial effort originates at an Urban League meeting and gains support from the Portland Development Commission (PDC), which agrees to seek federal funding and help with planning for the project.

1961 The League of Women Voters conducts a study of Black and white Portlanders living in integrated communities." Black families have higher educational levels than their white neighbors and are twice as likely to have two wage earners in the family. Surveyors conclude that "the problem is one of economics as well as of prejudice and discrimi- 


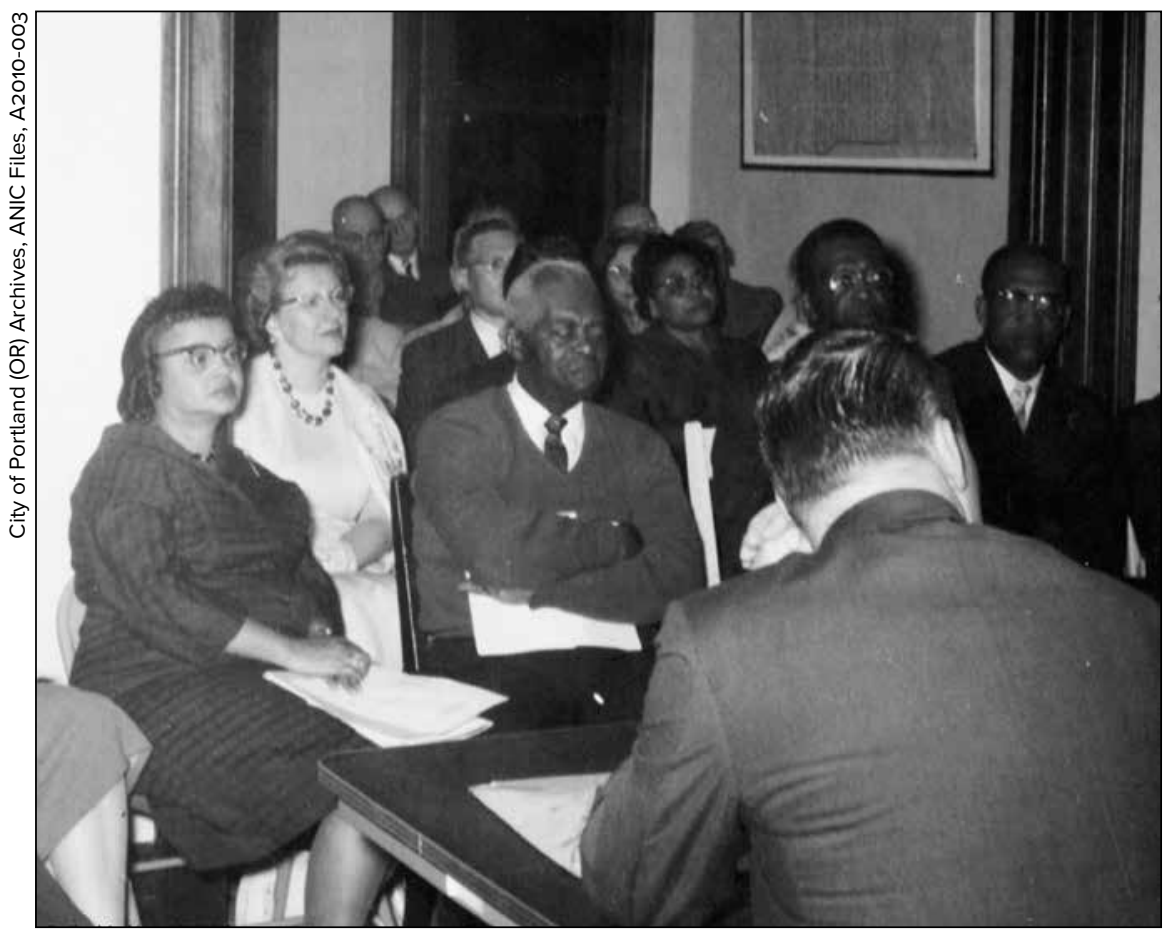

PORTLAND DEVELOPMENT COMMISSION representatives meet with residents at the Albina Neighborhood Improvement Center in April 1963.

nation," citing limited employment opportunities as one of the major barriers to housing integration. One Black family interviewed in the survey comments, "if there was adequate employment, a Negro could purchase the kind of house he wants."

In the post-war era, Blacks occupy only 2 percent of newly constructed housing.12 The older homes Black families reside in are often bought on contract with limited homeowner's insurance policies. Some families have to take out second or third mortgages and face higher interest rates and longer loan terms, alongside the high upkeep and repair costs of living in older housing.

1962 The League of Women Voters interviews eighteen real estate brokers about Oregon's Fair Housing Law. Although the law prohibits discrimination, one third indicate that the law is difficult to comply with because whites still refuse to sell their homes to Blacks, so many brokers make a "gentleman's agreement" not to show the property to any Black families. ${ }^{13}$ Real estate agents believe that if they violate the seller's wishes, they might lose business. The two Black brokers interviewed suspect there are "too many evasions and dodges" of the law and that white brokers and sellers get away with refusing to show homes to Black families because of lax enforcement.

The Albina Neighborhood Improvement Project (ANIP) begins in a zone bordered by North Fremont and Skidmore streets between Vancouver Avenue and Mississippi Avenue. ${ }^{14}$ The neighborhood rehabilitation project provides low-interest loans to residents to make home repairs. The population in this area is roughly evenly split between Blacks (54 percent) and whites (46 percent). The program also works on cleaning up streets and plans to create a park near Shaver and Kerby. Meanwhile, the PDC releases the Central Albina Study, which calls for a "unified plan" phased in over a decade to condemn, demolish, and rebuild the neighborhood directly south of the ANIP area from Fremont to Broadway, extending from the freeway to Northeast Seventh Avenue. The Central Albina area is home to 7,000 residents, 70 percent of whom are Black.

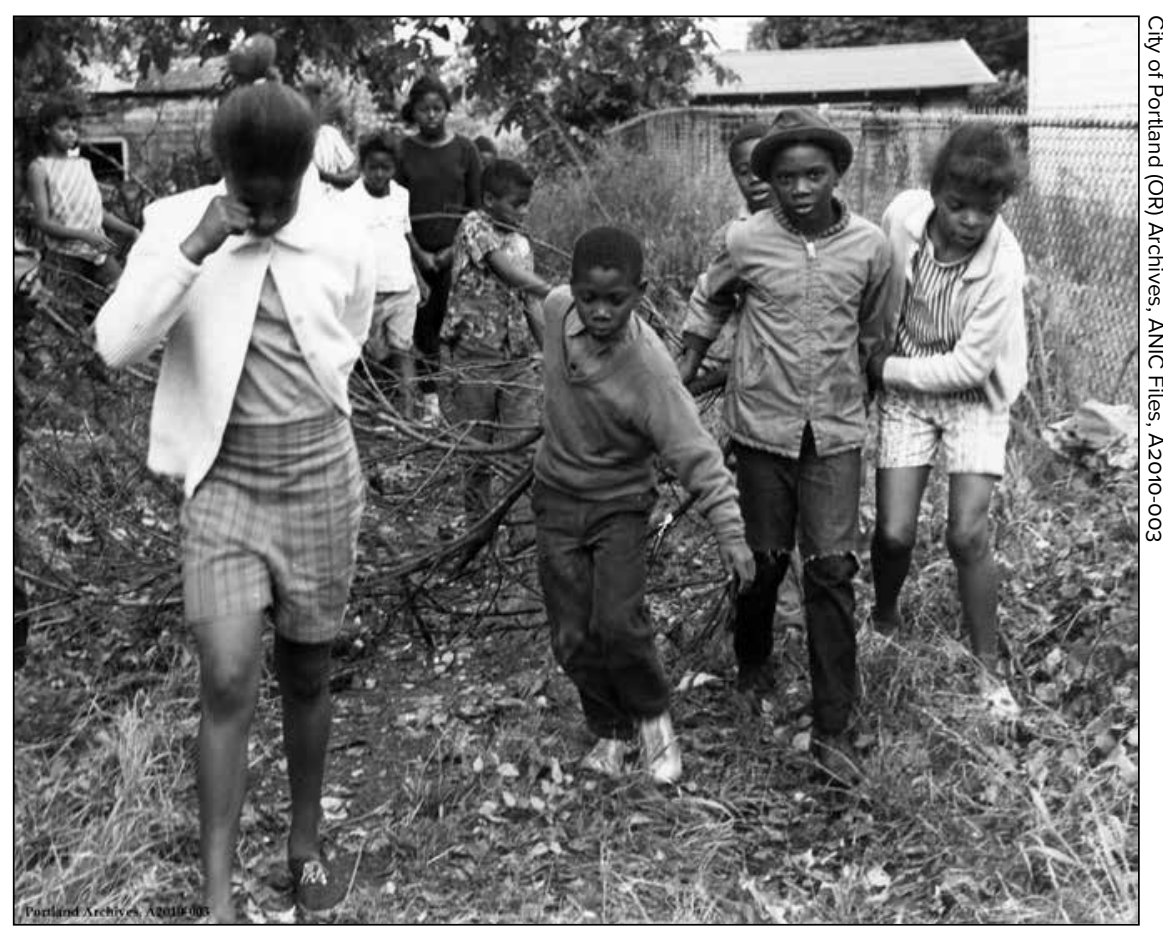

CHILDREN PARTICIPATE in the Albina Neighborhood Improvement Center neighborhood clean up in December 1962 
1962 The Housing Authority of Portland's (HAP) proposed Daisy Williams housing project in central Albina sparks protests by the Urban League, the NAACP, and church groups. ${ }^{15}$ Civil rights activists are concerned that the housing project will perpetuate ghettoization and school segregation. While only 15.5 percent of HAP residents are non-white, the Maple-Mallory complex in Albina is 98.5 percent non-white, and nearby Iris Court is 85 percent Black. When Robert Carter, the NAACP chief counsel, visits Portland, he notes that public housing authorities play a key role in "entrench[ing]" segregation, calling public housing the "adhesive that keeps ghettos glued together." Despite community concerns, planning for the project continues.

Samuel Macon and Nathan Jones file a racial discrimination complaint with the Oregon State Labor Board after the Portland Bureau of Parks refuses to rehire them for summer employment. ${ }^{16}$ Russell Peyton of the IGRC notes that there is a list of discrimination complaints against the Bureau of Parks at the Oregon State Labor Board that date to 1949. Bureau of Parks director Dorothea Lensch is found to have practiced "gross discrimination" by asking for photos with employment applications. In July, the city reaches a settlement with the Oregon State Labor Board, which drops the racial discrimination charges in exchange for extending employment offers to Macon and Jones. In August, City Commissioner Ormond Bean cancels his planned appearance at a post office ceremony, because the NAACP threatens to walkout to protest discrimination in the Bureau of Parks.

1963 At the request of the HAP, President John F. Kennedy cancels his planned visit to Portland to dedicate the Northwest Tower housing project after the NAACP threatens to picket, because the project is all-white. ${ }^{17}$ The Greater Portland Council of Churches notes that public housing projects in Portland are either "virtually all white or all Negro." Under pressure from civil rights and church groups, the City Council permanently tables the zoning changes that are necessary to move ahead with HAP's planned housing project in Albina, effectively stopping plans for the Daisy Williams complex.

1964 A review launched by the federal Public Housing Administration finds that HAP did not discriminate when it selected tenants for its Northwest Tower 150 -unit housing project for the elderly. ${ }^{18}$ The apartments were offered on a first-come, first-served basis, and two of the selected tenants were Black, although they turned down the apartments. The Intergroup Relations Commission (IGRC) gets involved in the controversy and invites the Greater Portland Council of Churches to share concerns about racial discrimination in HAP's housing assignment policies. The IGRC recommends policy changes to HAP's housing assignment process that include eliminating race on housing assignment forms, assigning all applicants a number, offering housing to applicants in the order they applied, and holding open, public meetings of the HAP commission. HAP expresses an interest in adopting these recommendations.

1966 The Portland City Council approves funding to hire a professional director and secretarial support staff for the Intergroup Relations Commission and changes its name to the Human Relations Commission (HRC). The eleven-member volunteer committee had been advocating for a professional position, noting that more than forty cities, including Seattle, already had full-time staff. In a letter of support for the position, the League of Women Voters argued that a "lay commission" on human relations can only get "token compliance" from institutions. ${ }^{19}$

1967 The NAACP lobbies the Legislature to add stricter penalties to Oregon's Fair Housing Law. ${ }^{20}$ The House passes a bill that allows victims of housing discrimination to collect up to $\$ 500$ in damages, but it fails in the Senate.

1967 The HRC intervenes after the Oregonian institutes a policy that requires subscribers in Albina to pre-pay for delivery. ${ }^{21}$ The Oregonian claims the independent dealers who contract to deliver papers make payment policy decisions. C-CAP, an Albina community organization, offers to take over delivery, but the issue is resolved when the dealer reinstates the old payment policy for all Albina residents who pay their subscription fees on time.

1967 The HRC works to counter neighborhood opposition to the HAP's proposed Hillsdale Terrace complex in Southwest Portland. ${ }^{22}$ Despite significant neighborhood pushback, the City Council approves the construction of the 70-unit project, although the unit sizes are reduced to 180 total bedrooms, down from the 240 originally planned.

1967 Of the 525 homes in the Albina Neighborhood Improvement Project Area, 165 have received low-interest loans and completed home repairs and improvements. Another 46 are in the process of making repairs, and 23 more have applied. ${ }^{23}$ The neighborhood has an 80 percent homeownership rate, higher than in the city overall, but 40 percent of the homes were purchased on contracts between sellers and buyers, rather than with traditional mortgage financing. In a contract purchase, the home title is often retained by the seller until the 
entire contract is paid off. HUD does not allow contract-purchased homes to be used as collateral when applying for a loan. This situation poses a challenge for ANIP workers. To get around it, the staff works with the buyer and seller to renegotiate a mortgage arrangement. As a result, it takes four times as long for contract-purchase homeowners to apply for home repair loans. Despite these difficulties, not one homeowner in the ANIP has defaulted on their loan.

The PDC receives a planning grant for the four-stage Emanuel Hospital Urban Renewal Project. ${ }^{24}$ The project will require the acquisition of nineteen neighborhood blocks and the displacement of residents and businesses.

1969 The HRC becomes the Metropolitan Human Relations Commission (MHRC), after a city-county coordinating committee agrees to expand the scope of the organization to cover all of Multnomah County. ${ }^{25}$ The expanded commission has fifteen members.

In late 1970, the PDC begins the next phase of the Emanuel Hospital Urban Renewal Project, which targets for clearance the neighborhood bordered by North Kerby Street and North Williams Avenue and between North Russell and Cook streets. ${ }^{26}$ Residents form Emanuel Displaced Persons Association (EPDA) and file a complaint with HUD to block the demolition, claiming that PDC used faulty and outdated information to show that adequate replacement housing existed for those being displaced. The EPDA negotiates an informal settlement "treaty" with PDC and other agencies that calls for 200 to 300 units of federally funded low- to moderate-income replacement housing to be built as part of the urban renewal plan.

The displacements proceed, but there is little effort made to plan or construct replacement housing. The MHRC issues a statement decrying the "cavalier attitude" of the PDC and suggesting that residents have been "frightened, cajoled, and seduced" into making a settlement to surrender their property. ${ }^{27}$ The EPDA organizes an open hearing, so residents can air their grievances, but the MHRC does not attend, so the EPDA issues a "no confidence" vote in the human relations commission. The MHRC conducts a follow-up survey in the neighborhood to better understand residents' concerns. The MHRC decision to have the Police-Community Relations Unit administer the survey prompts suspicion from some residents and uncertainty over the validity of the results. The survey shows that over 43 percent of respondents are not satisfied with relocation and that attitudes toward PDC are mixed.

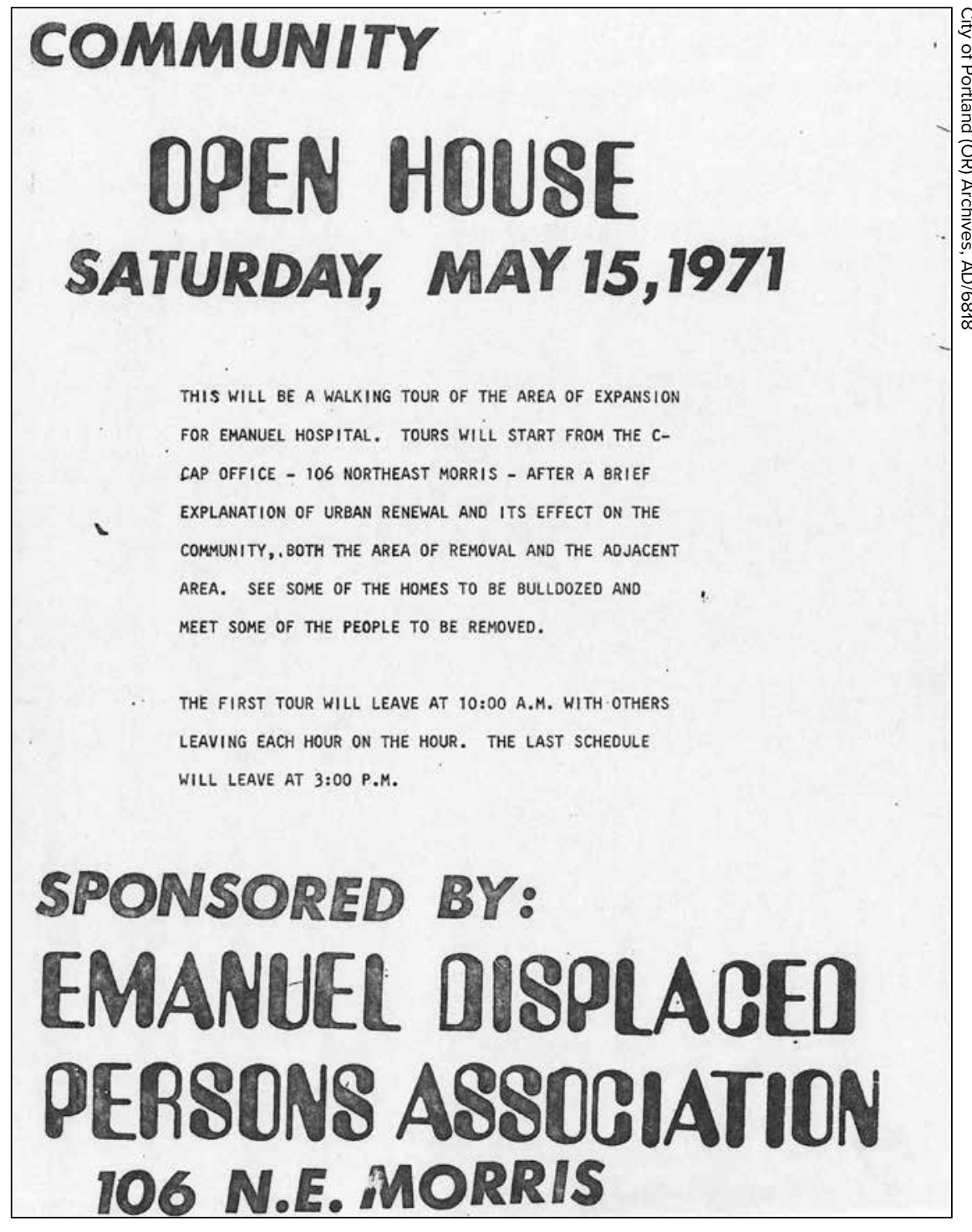

THIS FLYER for a community open house on Saturday May 15, 1971, invites area residents to tour the Emanuel Hospital expansion. The event was sponsored by the Emanuel Displaced Persons Association (EPDA) and organized to give residents an outlet for their grievances.

1971 Civil rights and community organizations collect citizen complaints about how it is "virtually impossible" to fully insure homes and businesses in Albina. When Albina resident Gavin Campbell writes a letter 
of complaint to the State Insurance Commission about the problems he encountered when he tried to insure his shop on Northeast Russell Street, he is shocked by the dismissive reply from the chief deputy commissioner. "The tone of his letter makes one wonder if he owns $90 \%$ of the stock in the Royal Globe Insurance Companies." 28

The State Insurance Commission refers Albina residents who complain to the Fair Access to Insurance Requirements (FAIR) plan.. ${ }^{29}$ (FAIR was a federal plan that began in 1966.) It is administered through private insurance companies and regulated by the State Insurance Commission. FAIR offers affordable property insurance in high-risk areas by pooling the risk across participating companies. Insurance agents are often reluctant to inform customers about the plan, however, because agents can earn only a 10 percent commission on FAIR policies, instead of their typical 20 to 25 percent commission. The FAIR plan does not provide burglary or liability insurance coverage.

Since only 72 policies were issued under the FAIR plan, the MHRC and other civil rights organizations seek a legislative fix, pushing for a bill that would ban discriminatory insurance practices based on location. The State Insurance Commissioner, however, backs an alternative plan to strengthen the FAIR plan and promote it. The reformed FAIR plan would become law in 1971, and civil rights organizations note the growth in the substandard insurance markets in Albina. Rather than issuing FAIR plans, insurance agents direct Albina homeowners to companies that charge up to three times the usual rates. This practice remains legal under Oregon law.

1971 Representatives of thirty-six building and construction trade unions, white and minority contractors, and civil rights groups adopt the Hometown Plan, a voluntary labor accord designed to increase the representation of minorities in building trades and contracting. ${ }^{30}$ Yearly targets for minority recruitment to apprentice programs and promotion to journeyman status are included.

The City of Portland adopts an affirmative action plan for employment in all bureaus. ${ }^{31}$ The ordinance follows the issuance of new federal guidelines that require local governments to have equal opportunity policies to qualify for grant money. The county also adopts a plan that creates an equal opportunity advisory committee in each department to review hiring policies and recommend changes. definitely postponed after funding falls though due to the expiration of a federal hospital construction loan program. ${ }^{32}$ The PDC began clearing the area before funding was secured, permanently displacing 162 families and bulldozing a 22-block area that now sits empty.

1975 Despite the voluntary Hometown Plan to increase minority representation in building and construction unions, a survey finds that only 1.9 percent of trade unionists are minorities..$^{33}$ About half are in the Laborer's Union, which is not a "critical craft" targeted by the Hometown Plan. The United Minority Workers, one of the signatories to the Hometown Plan, files a complaint with the Labor Department, which withdraws its support for the plan. The plan committee had been floundering from a lack of federal funding and had not kept records. The withdrawal of Labor Department support means Portland is now subject to federa regulations that require at least 5.5 percent minority representation in unions hired to complete federally funded projects.

1976 In June, as the 1975 Home Mortgage Disclosure Act goes into effect, the Federal Reserve orders banks to disclose the home loans they made by census tract and zip code..$^{34}$ Lenders in Portland insist they do not redline, yet Ernie Bonner, the director of planning for the city, is unable to get a loan to purchase a home in the Sunnyside neighborhood. A realtor in Irvington notes that lenders flee "at the first glimpse of trouble" in a neighborhood and "they'll be the last ones in." The mayor's office reaches out to major lenders in the Portland metropolitan area, asking about their practices. The banks proclaim that they do not redline and instead point to inner city lot sizes, zoning, and off-street parking as reasons for not issuing home loans. In October, the city establishes the Portland Metropolitan Residential Loan Review Committee. The committee, comprising representatives from the region's major home-lending banks, reviews complaints about loan denials. The complaints are first screened by the PDC, then sent to the committee for review. If the committee determines that a loan was denied because of neighborhood conditions, it is sent back to the bank for reconsideration.

Oregon Student Public Interest Research Group (OSPRIG) conducts a pilot study about redlining ${ }^{35}$ Researchers with the group call banks seeking financing for a fictitious property near Northeast Thirteenth and Killingsworth. One bank tells the researcher it does not make loans on properties north of Fremont and west of Northeast Fifteenth. The second bank asks if the caller plans to live in the house. When the caller responds affirmatively, the banker replies, it "might be better considered an investment property" due to its location. 
1977 The Oregon Association of Realtors and the Department of Housing and Urban Development enter into a voluntary agreement to affirmatively market more homes to women and minorities. ${ }^{36}$ The voluntary pact exempts the association from having to file an affirmative action plan, as participants in FHA and Veterans' Administration housing programs are required to do.

1977 Legal Aid files a class-action lawsuit against the director of the Oregon Bureau of Labor and Industries, which oversees the Civil Rights Division (CRD), the state attorney general, and the assistant attorney general. ${ }^{37}$ The suit alleges that the CRD does not have adequate resources to process complaints and that discrimination complaints are intentionally slow-walked. In civil rights cases, it takes from four to six years for a complainant to get a hearing, while wage complaints, which are handled by the same bureau, are usually resolved within four to eight months.

OSPIRG releases its completed redlining report. ${ }^{38}$ Using Home Mortgage Disclosure Act data from the eight largest lenders, the organization had estimated the anticipated number of loans that should be made in each neighborhood based on the banks' lending rates. The report finds that North, inner Northeast, Downtown, and the Corbett/ Terwilliger neighborhoods had disproportionately low mortgage issuances, while lending rates to communities in Washington and Clackamas counties were disproportionately high. In inner Northeast Portland, only half of the expected loans were made, and in North Portland, lending occurred at about one third of anticipated levels.

The report notes that many of these banks collect deposits from residents in the communities they refuse to support with loans. Willamette Savings and Loan has a branch on Union Avenue and Killingsworth, but has no loan officers working there. Many banks centralize their home lending departments in offices in the suburbs. Inner-city customers are essentially helping to subsidize suburban development with their deposits.

The Metropolitan Loan Review Committee has not reviewed any loans in its two years of existence. Screening by the PDC failed to find any complaint worthy of the committee's review. The PDC will only approve a complaint for review if a loan was expressly denied because of its location. In 1978, a loan for a house on Northeast Stafford Street is denied, because it is near a street with heavy traffic and railroad lines. ${ }^{39}$ This was an FHA loan, and the denial was upheld, because the property did not conform to FHA standards. Pat La Crosse from the PDC claims "lenders are falling all over themselves to make loans within the inner city," and the complaints his organiza-

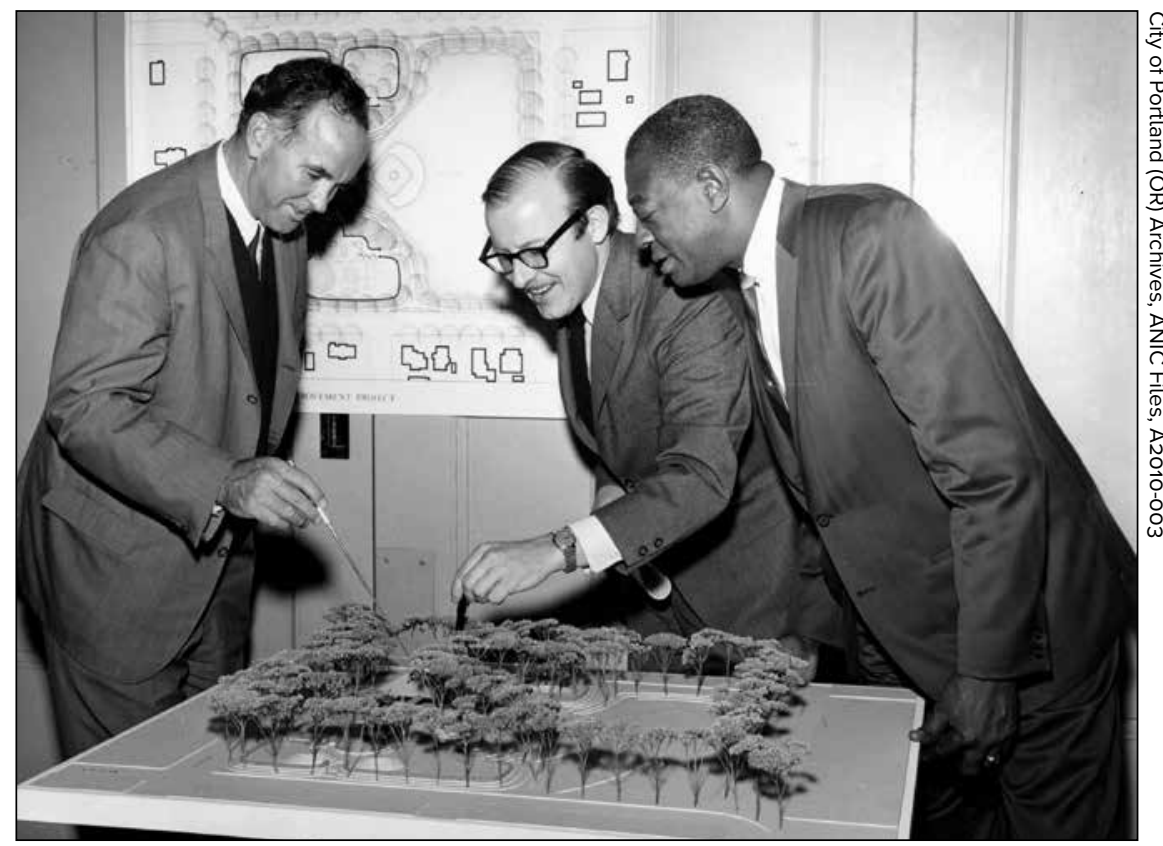

IN DECEMBER 1963, John Kenward, Robert Perron, and Herman Plummer (Albina Neighborhood Improvement Project project manager) inspect a model of Unthank Park, an eighty-unit public housing project for low-income seniors.

tion screens out from the Loan Review Committee have nothing "to do with location or age" of the home.

When confronted with OSPRIG's statistics, the banks claim that more homes are purchased on contract in these neighborhoods..$^{40}$ The report notes that in 1976, nearly 20 percent of homes in Multnomah County were bought on contract, although this type of sale often occurs when there is lack of traditional financing available. The banks argue that, because homes in the underserved neighborhoods are older, they are of ten substandard and would need to be brought up to code to be eligible for a loan. Adding home repair loans to the mortgage would exceed the total value of many of these properties. The lenders also indicate that there are other Portland banking institutions known for lending in inner city areas, yet federal law requires all banks to offer loans to all the neighborhoods they serve.

1978 HAP opens Unthank Plaza, an 80-unit public housing project for lowincome seniors built on land that was cleared during the Emanuel Hos- 
pital Urban Renewal Project. ${ }^{41}$ One third of the units are set aside for eligible residents who were displaced by the urban renewal project. The PDC sells a ten-block parcel bulldozed under the plan to Emanuel Hospital, which has no immediate plans for development.

1979 The Portland Board of Realtors signs a Voluntary Affirmative Marketing Agreement (VAMA) with HUD to promote equal housing opportunities. ${ }^{42}$ VAMA signatories create programs that focus on non-discriminatory advertising, train and guard against racial steering, and increase the recruitment of minorities in real estate. A Community Housing Resource Board is established by HUD to monitor and oversee VAMA implementation.

1979 The MHRC institutes a housing-discrimination checking service. ${ }^{43}$ Portland area residents who have been discriminated against can file a complaint with the MHRC. The checking service will test for discrimination and support victims through the HUD or Oregon Civil Rights Division complaint process. The MHRC also helps with landlord-tenant disputes and provides referrals for legal support.

1980 Legal Aid settles its class-action lawsuit against the Oregon Civil Rights Division, because under new leadership, the department has improved its response times. ${ }^{44}$ In a five-year review of the Civil Rights Division, the MHRC finds that there was a backlog of complaints dating to 1969 but that, after new processes were instituted, complaints are now resolved within 130 days. Failure to investigate complaints in a timely manner makes it difficult to follow up and to test for discrimination.

Since the MHRC established its checking system, more housing discrimination complaints have been settled in the complainant's favor. Prior to the checking service, just 17.4 percent of complaints were settled; with the new system, the settlement rate increased to 24.9 percent. Gary Gomez, the new CRD director, is concerned about "systemic discrimination." The MHRC suggests maintaining a list of complaints, so the extent of discrimination can be tracked, repeat offenders identified, and the impacts of education and training programs assessed. ${ }^{45}$

In testimony on changes to the metropolitan region's land use plans, the MHRC notes that "Portland is a segregated city" and that segregation is not only a result of discrimination but also of "economically exclusionary zoning patterns." Some of the economic barriers that prevent integration include: a lack of affordable housing, poor credit scores, employment status, and the lack of promotional opportunities.
1980 Three incidents of racial terrorism spark fears about a resurgence of the Ku Klux Klan (KKK) and other hate groups in Oregon. ${ }^{46}$ Kwaku Boateng's family is subjected to repeated harassment and racially motivated vandalism after they move to St. Helens, Oregon. The ongoing harassment drives the family out of the Columbia County town. In Salem, Maurice Harmon, a state worker, is attacked at bar by a man shouting racial epithets. His house had been damaged weeks earlier when an unknown assailant threw Molotov cocktails at it. Roy Richardson's family has thei cars vandalized and a cross burned outside their Milwaukee home. The increase in racially motivated attacks prompts Gov. Vic Atiyeh to propose legislation to make racial harassment a felony crime.

1981 The Oregon Legislature passes a racial harassment law, which make intimidation based on race, color, religion, or national origin a misdemeanor crime punishable by up to one year in jail. ${ }^{47}$ Like other hatecrime laws, the intimidation charge is added on top of charges of assault, menacing, or criminal mischief.

1981 Although HUD signed a VAMA with the Portland Board of Realtors in 1979, the federal agency has yet to institute a Community Housing Resources Board to oversee and enforce the voluntary agreement. ${ }^{4}$ The MHRC considers establishing its own oversight committee if HUD refuses to act. The MHRC signs an agreement with the Multifamily Housing Council, Oregon Apartment Association, and other landlord groups to address discrimination against families with children in rental housing. Sixty percent of multifamily properties and 21 percent of single-family rental homes prohibit children. Under the agreement, training will be provided and more housing opened up for families.

1983 The Housing Integration Task Force, which began in 1980 to discuss alternatives to school busing, surveys Portlanders' attitudes about neighborhood integration. Fifty six percent of respondents express the desire to live in an integrated neighborhood. Ninety three percent of Blacks surveyed preferred integrated neighborhoods. ${ }^{49}$ Support for integration is greater on the eastside, with the highest support coming from inner North, Northeast, and Southeast neighborhoods. The Southwest area has the lowest levels of support for integration. Portlanders over age sixty and white housewives express the most discomfort with integration and gave prejudice and safety concerns as their reasons for opposing racially mixed communities. Few opponents of integration cite concerns about property decline, indicating that myths that had fueled blockbusting and white flight no longer hold sway. 
1984 The Community Housing Resources Board created by HUD to oversee its Voluntary Affirmative Marketing Agreement with the Portland Board of Realtors finds "substantial deficiencies" in the implementation of the agreement. ${ }^{50}$ At this point, 73 percent of Black Portlanders live in inner Northeast. Eighty six percent of Black owner-occupied units are located in the North and Northeast neighborhoods. Only 12 of the 1,300 members of the Portland Board of Realtors are racial minorities.

The City of Portland adopts a fair-housing strategy that involves increased education, training and outreach, housing referral and assistance programs targeting minority families, housing rehabilitation programs, homebuyers' workshops, and efforts to recruit more minority realtors. ${ }^{51}$ The MHRC had received more than 200 housing discrimination complaints in 1985 .

Dominion Capital begins operating in Portland. ${ }^{52}$ Dominion lends money to shady real estate investors who purchase large numbers of homes from desperate sellers. The investor offers a substantial down payment, then asks the seller to carry a contract for the outstanding value of the deal, with the full amount due in two to three years. Property Investments Incorporated, owned by Cleveland and Michelle Brigham, have entered into numerous contracts in inner Northeast Portland, then failed to pay the contract when it came due. Because the Brighams are in debt to Dominion Capital, the company acquires these homes. Thirteen sellers file suit against the Brighams, claiming they are victims of fraud.

Portland banks issued only nine mortgage loans in the inner Northeast neighborhoods between Fremont and Killingsworth streets and stretching from Albina to Northeast Fifteenth avenues. The area is home to 12,000 residents, 70 percent of whom are minorities. ${ }^{53}$

The Oregonian conducts a study of mortgage lending practices in Portland. In inner North and Northeast Portland, banks make only a quarter of the loans they make in other areas. ${ }^{54}$ In the neighborhoods with the largest concentrations of Black residents, banks lend at onesixth the rate. No federally insured mortgages, which are designed for low-income and first-time home buyers, had been issued in the four predominately Black census tracts.

Most homes in the area sell for less than $\$ 25,000$. The banks almost always refuse to make loans under $\$ 30,000$, and if they do, they charge higher interest rates for them, even though a national mortgage industry-sponsored study showed that small mortgages are very low risk. Without easy access to lending, nearly half of all real estate transactions in inner North and Northeast Portland are done in cash or arranged by private sellers on contract.

In the void left by the banks, Dominion Capital purchased more than 350 homes in inner North and Northeast Portland, both on its own and through straw buyers, such as the Brighams. The company markets these homes to inner Northeast residents with deals that in volve low move-in costs and monthly payments. The homes are sold on contract, with the full amount of the loan due in five years. Dominon retains the title until the contract is paid off. The purchase price is highly inflated, because it includes the outstanding loan amounts from the straw buyers. Buyers end up owing far more than the home is really worth. Already under scrutiny from the state, Dominion files for bankruptcy after Attorney Dave General Frohnmayer files suit against the company, leaving buyers at risk of losing their homes.

\section{NOTES}

Carmen P. Thompson

1. This was said as part of conversation between Morrison and Dr. David Roediger at the University of Minnesota; he is not sure of the date but would often mention these comments in classes I took with him while in my doctoral program at the University of Illinois.

2. August 3, 1857, Frederick Douglass "West India Emancipation" speech at Canandaigua, New York.

3. Since 2014 PAALF has partnered with organizations such as PCRI. PAALF's initiative "Your Right to Return Home" under its Peoples Plan links it with organizations such as PCRI. Comments by PCRI director and PAALF member Maxine Fitzpatrick, in a February 4. 2014 article in The Skanner says a goal in Northeast Portland made available to displaced former residents. Specifically, PCRI with the support of PAALF is developing a plan to build 1,000 new affordable homes in North and Northeast.

\section{Greta Smith}

1. Greg Nokes, "Black Exclusion Laws in Oregon," The Oregon Encyclopedic https://oregonencyclopedia.org/articles/ exclusion_laws/\#.W32Pqc4zrmE (accessed August 22, 2018).

2. Richard Rothstein, The Color of Law A Forgotten History of How Our Government Segregated America (New York, London: Liveright Publishing Corporation, 2017) 77, 78 . 3. Ibid.

4. Ibid., 78-80. 
both as quoted in City Club of Portland, "The Negro in Portland," 62.

21. Rough draft of letter from Gladys Hindson (president of the NAACP Portland Branch) to the Portland Realty Board 1949 , NAACP of Portland Oregon records, ca. 1914-1986, University of Oregon Libraries, Special Collections and University Archives.

22. Press release from Portland Branch NAACP Federal Credit Union, January 26, 1982, Rutherford Collection, box 5 , folder 48 PSU Special Collections.

23. Robin Kigel, "It Reminds Me of a Neighborhood I Used to Live in in East Harlem': A Slum in the Livable City and the Politics of Housing Abandonment in Portland Oregon," (M.A. paper, Portland State University, Marc 11, 2014), 5 , in possession of the author

24. Melissa Lang, "Lifting as We Climb: African American Women Organizers in Portland, Oregon, 1912-1957," Oregon Women's History Consortium Fellowship Report, September 2016, available online at http://www.oregonwomenshistory.org/wpcontent/uploads/2017/og/OWHC_Lang_finalwith-images.pdf (accessed July 25, 2018): Press release from Portland Branch NAACP Federal Credit Union, January 26, 1982 Rutherford Collection, box 5, folder 48, PSU Special Collections.

25. Robert L. Harris, Jr. "Early Black Benevolent Societies, 1780-1830," Massachusetts Review, 20: 3 (October 1979) 603-25.

26. NAACP Annual reports, 1957, 1964 1975, Rutherford Collection, box 5, folders 45-47, PSU Speciol Collections.

27. NAACP Portland Chapter, Federa Credit Union, Rutherford Collection, 1960s, box 5 , folder 46 , PSU Special Collections.

28. "Who We Are" Point West Cred 28. "Who We Are," Point West Credit com/who-we-are/about-point-west/ (accessed August 1, 2018).

29. Robert Landauer, "Black-Owned Loca Bank opens Branch Operation," Oregonian, January 19, 1971, p.13; Donald J. Sorensen, "In non-Black area Black bank will open branch office," Oregonian, January 6, 1976, p. A13.

30. Sorensen, "In non-Black area Black bank will open branch office," Oregonian, p. A13.
31. Ibid.

32. Portland City Council Minutes, December 30, 1942, microfilm, A2018-011,

33. Gibson, "Bleeding Albina," 7

34. Scrapbook 2, 1942-43, A2001-025, PARC; "New Negro Migrants Worry City," Oregonian, September 23, 1942, p. 1; City of Portland Bureau of Planning, "The History of Portland's African American Community, 1805 to Present (Portland: Portland Bureau of Planning, 1993), 60.

35. "X-Religion: Cooperation with Organized Religious Groups," document from national NAACP Convention, July 3, 1965, NAACP Records (unprocessed collection), box 1 of 7, folder "NAACP Branch Business," MSS 2004, OHS Research Library

36. Mervin Shoemaker, "Housing Agency Asks JFK to Cancel Visit: Negro Group's Picket Threats Raise Question," Oregonian, September 19, 1963, p.1

37. Ibid.

38. Kigel, "It Reminds Me of a Neighborhood I Used to Live in in East Harlem,", 5-9.

39. Ibid., 24-25.

40. The Urban League of Portland and the NAACP Portland Branch are active and seeking volunteers: Urban League: https:// ulpdx.org/; NAACP Portland Branch: https:// pdxnaacp.org.

A special thanks to Mary Hansen and all of the staff at the City of Portland Stanley Parr Archives and Records Center.

Memo to Human Relations Commission members from Tom Sloan dated August 22 1968: "The Human Relations Commission," dated April 24, 1969; Memo from Vernon Summers to the Human Relations Commission, dated May 13, 1969; all at General Business, 1968-1969, A2001-022, City of Portland Archives and Records Center, Portland, Oregon [hereafter PARC].

2. HUD study noted in memo from Charles Jordan to Mildred Schwab, Neil Goldschmidt, Frank Ivancie, and Connie McCready dated October 8, 1976, Housing and Community Development, 1975-1979, A2001-010, PARC
3. "Bill on FEPC Given Senate," Oregonian, January 12, 1949, p. 8; Paul Hauser "House Adopts FEP Measure by 53-4 Count," Oregonian, March 20, 1949, p. 1

4. "Pastor to Head Racial Studies," Oregonian, February 10, 1949, p. 10.

5. Ordinance 91214, PARC; Dan Horstch, "City Rejects Ordinance for Equality,"

Oregonian, November 8, 1982, p. 34.

6. Ibid.

7. Mervin Shoemaker, "Senate Votes Action Aimed at Prejudices," Oregonian, March 17, 1953, p.1.

8. William Swing, "Conference Deplores Segregation in Housing," Oregonian, March 2.1958, p.18: "Community Workshop on Equal Opportunities in Housing," The Urban League of Portland; "Don't be Misled" pamphlet, all in Fair Housing, A2001-022, PARC

9. League of Women Voters, An Examination of the Attitudes, Policies, and Procedures Which Affect the Application of Oregon's 1959 Fair Housing Law (Portland: League of Women Voters, May 1962), in the Orenon Historical Society Research Lib the Oregon [hereafter OHS Research Library], ii; Mervin Shoemaker and Ken David, "Centennial Legislature Digs Bottom of the Barrel for
Funds," Oregonian, May 10, 1959, p. 27; "Civil Funds," Oregonian, May 10, 1959, p. 27; “Civil Rights Bills Discussed at Hearing," Oregonian,
April 9, 1959, p. 9.

10. James Lattie, "Albina Fights Woes Age," Oregonian, July 28, 1963, p.1.

11. League of Women Voters, An Examination of Attitudes, 2

12. Ibid., 5 .

13. Ibid., 8-11.

14. William Sanderson, "Cooperation Creates Attractive Homes in the Albina Area," Oregonian, July 18, 1967, p. 26; James Lattie, "Albina Project Moves with Unity of Races,"Oregonian, July 29, 1963, p. 26; James Lattie, "Commission Director Sees Challenge in Albina Renewal Plan," Oregonian, July 31, 1963, p. 10

5. "Urban League Claims Housing Project Promotes Segregation," Oregonian, May 11, 1962, p. 30; William Hillard, "Fuss Raised over Site for Low Rent Housing Units," Oregonian, March 18, 1962, p. 33. William Swing "NAACP Chief Counsel Says US Public Housing Rulings
Delay Desegregation Process," Oregonian, April 6, 1962, p. 25.

16. Letter to Terry Schrunk from Harold Glen Brown, dated June 25, 1962; "Rough Notes in Regard to Discrimination in the Parks Bureau," first draft dated June 17, 1963, both in Parks Discrimination Charges, 04-07-01, PARC; Bean Cancels Ceremony Appearances to Avoid Walkout by NAACP," Oregonian, August 15, 1963, p. 40

17. Mervin Shoemaker, "Housing Agency Asks JFK to Cancel Visit: Negro Group's Picket Threats Raise Question" Oregonian, September 19, 1963, p. 1; "Committee on "intergroup Relations Meeting Minutes," January 15, 1964, A2001-002, Intergroup Relations Commission, 1964, PARC. Thomas Albright, "Poor Judgement General," Oregonian, September 25, 1963, p. 22; "City Council Makes Swift Move to Avoid Racial Bas Charge," Oregonian, August 1, 1963, p. 22.

18. "Intergroup Relations Commission Report on Portland Housing Authority," February 11, 1964: "Intergroup Relations Commission Meeting Minutes," August 19 in A2001-002, Intergroup Relations Commission, 1964, PARC: "HAP Clearod Again," Oregonion, Februaty 11, 1964, P. 14 19. "City Council Approves $\$ 15,000$ Budget for Portland's Human Relations Team," Oregonian, April 30, 1966, p. 14; “Name Changed," Oregonian, April 30, 1966, p. 16; Letter to Terry Schrunk from Mrs. Thomas E. Robinson, dated March 2, 1966, Intergroup Relations Commission, 1966, A2001-002, PARC.

20. William Conway "Oregon among 21 ( Housing Laws," Oregonian. ust 25, 1967, p. 14.

21. Untitled document \#345, Human Relations Commission, 1967, A2001-002, PARC; "Human Relations Committee Annual Report, 1967," Human Relations Committee, 968, A2001-002, PARC.

22. "Human Relations Committee Annual Report, 1967," Human Relations Committee 1968, A2001-002, PARC; "HAP Hopes to Quiet Fuss by Shrinking Apartments," Oregonian, January 11, 1967, p. 12; Andrew Mershon, "After Eight Argument-filled Hours, HAP Project Sent to Committee," Oregonian, April 27, 1967, p. 1; "City to Get Hillsdale Compromise," 
Oregonian, May 5, 1967, p. 37

23. William Sanderson, "Cooperation Creates Attractive Homes," Oregonian, July Crest 1067. . 26

24. "Planning Grant Approved for Emanuel Hospital Urban Renewal Project, Oregonian, December 4, 1968, p. 20

25. "City-County Body Okayed," Oregonian, December 24, 1969, p. 7.

26. "Emanuel Residents Contest Renewa Project," Oregonian, December 3, 1970, p. 36; "7.5 million Emanuel Project Stalled over Disputed Availability of Housing," Oregonian January 12, 1971, p. 68; "Parties to Emanuel Renewal Project Prepare 'Treaty' to House Displaced," Oregonian, March 25, 1971, p. 35

27. Statement by MHRC concerning displacement for urban renewal; letter to John Kenwald, PDC, from Russell Peyton, MHRC dated June 25, 1971; letter to MHRC from Mrs. Leo Warren, undated; memo to Resident of Urban Renewal Area from Russell Peyton, MHRC, dated September 16, 1971 all in Emanuel Hospital Displaced Persons Correspondence A2001-022, PARC. James HiL, "Emanuence, Unit Forgos Hearing on Relocalion Plas." Oregonian, September 29, 1971, p. 40

28. Letter to Robert Elliott, Chair of the Urban Affairs Committee for the Orego Legislature, from Reverend Eugene Boyd, dated February 4, 1971; Letter from Gavin Campbell to E. Shelton Hill, the Urban League, dated April 13, 1970, Metropolitan Human Relations Commission Insurance Complaints, A2001-002, PARC.

29. "Property Insurance through the Oregon FAIR Plan" pamphlet; "Memo on Insurance," Insurance Committee Meeting Minutes, June 15, 1970; "Statement on House Bill 1377," Metropolitan Human Relation Commission Insurance Complaints, all in A2001-002, PARC; Jud Randall, "Commission Backs Expansion of Proposed High-Risk Insurance Law," Oregonian, March 3, 1971, 31; Robert Olmos, "Blacks Claim Only Second-Rate Insurance Available in Albina, Oregonian, May 30,1971 , p. 86

30. "Hometown Plan Shift Readied for Approval," Oregonian, September 23, 1971, p. 60
31. "City Council Okays Equality Ordinance," Oregonian, March 2, 1972, p. 16. Context and grant compliance with county documen ato "MHRC Review of County EEOC Programs" "MHRC Equal Opportunity and Affirmativ" Action Conual Opportunity and A2001-002, PARC.

32. Paul Pintirich, "Expansion leaves a 'Wasteland', Oregonian, April 15, 1973, p. 1.

33. James F. Warren, "Survey of Minorities in Portland Unions," August 26, 1975; "Civil Action Complaint to the U.S. Department of Labor by United Minority Workers": all in Hometown Plan 1972-1976 Affirmest, alt in A2001022, PARC; Jane Goetze, "Mine Action, Rejected Because of Complaint," Oregonian, December 5, 1975, p. 22.

34. Wayne Thompson, "Act won't affect loan polices," Oregonian, June 12, 1976, p. 13; Gordon Oliver, "Lenders Operate under Pressure from Guidelines," The Community Press, March 24, 1976; Letter to Loan Department Personnel from Louis Scherzer Ben Franklin Savings and Loan, dated March 11, 1976; letter to Neil Goldschmidt from Rollie Waters, Equitable Savings, dated March 30, 1976; letter to Neil Goldschmidt from C.J. Welch, Vice President and Manager, Pacific First Federal Savings, dated March 22. 1976, all in Housing Redlining General Correspondence 1974-1979, A2001-037, PARC; "A Historical Review of the Portland Metropolitan Residential Loan Review Committee," Loan Review Committee 1979, A2001-037, PARC

35. Michelle Haynes and Charles Harris, Report (Portland: OSPIRG, 1978), p. 15 in Multnomah County Public Library.

36. "Realtors Vow to Boost Equal Housing Efforts," Oregonian, May 26, 1977, p. 67.

37. John Painter, Jr., "Suit Cites 3 Officials

38. Haynes and Harris, The Facts Behind me Financing.

39. Minutes, Portland Loan Review Committee, September 9, 1978; Minutes Portland Loan Review Committee, August 21, 1978; and photocopied Oregonian and OR
Journal articles, all in Loan Review Committee 1979, A2001-037, PARC

40. Haynes and Harris, The Facts Behind Home Financing.

41. Michael Alesko, "Housing Project Opens its Doors," Oregonian, October 5 , 1978, p. 18; Alan Ota, "Last Shot Being Fired in Black Community's Urban-Renewal Battle," Oregonian, June 1, 1978, p. 20.

42. New Horizons Fair Housing Task Force, "Fair Housing Strategy Plan for the City of Portland," May 1986, MHRC Housing Committee Meeting Minutes, 5800-01, A2001022, PARC; U.S. Department of Housing and Urban Development "Overview of Voluntary Affirmative Marketing Agreements," available online at https://www.hud.gov/sites/ documents/80212C1FHEH.PDF (accessed on March 3, 2018).

43. Addendum to "Quarterly Report on Voluntary Fair Housing Activities," MHRC, dated February 28, 1979, MHRC Housing Committee Minutes of Meetings, A2001-022, PARC: "Program Aids Housing Discrimination Victims," Oregonian, March 18, 1979, p. 56

44. "Class Action Suit Settled," Oregonian, July 12, 1980, p. 9: "Fair Housing," dated August 8 , 1980, MHRC Housing Committee Meeting Minutes for December 10, 1980, dated December 16 1980; MHRC testimony on Recommended Comprehensive Plan Land Use Amendments, dated August 5, 1980; Memo to Jim Sitzman from Charles Jordan, "Economic Barriers to Integrated Housing" "September 11, 1980, all in Metropolitan Human Rights Commission Housing Committee, Reports, A2001-022, PARC.

45. "Fair Housing," August 8, 1980, in Metropolitan Human Rights Commission Housing Committee, Reports, A2001-022, PARC.

46. Alan Ota, "Racial Harassment Incidents Increasing in Oregon," Oregonian, December 21, 1980, p. 1; Julie Tripp, "Racial Threats Plague Milwaukee Area Family," Oregonian. August 17, 1980, p. 1; Richard Read, "Technical Blemish Kills Harassment Law Appeal," Oregonian, December 8, 1982, p. 80.

47. Charles Beggs, "House Panel 1990, p. A1.
Approves Racial Harassment Bill," Oregonian, May 22, 1981, P. 53. Fred Leeson, "Minorites but at a Slower Pace," Oregonian, October 8, 1984, p. 36.

48. Metropolitan Human Rights Commission Housing Committee minutes March 10, 1981, dated March 12, 1981, Metropolitan Human Relations Housing Committee, Reports, A2001022, PARC; Julie Tripp, "Children Get Break with act," Oregonian, April 21, 1981, p. 44.

49. Memo from Scott Jones, "Housing Integration Task Force Staff Survey--Summary and Comments," Metropolitan Human Relations Committee, Housing Committee Reports, Minutes and Correspondence, A2001-022, PARC; Spencer Heinz, "Survey Indicates Portlanders Favor Integrated Neighborhoods," Oregonian, November 8 , 1983, p. 80.

50. New Horizons Fair Housing Task Force, Fair Housing Strategy Plan for the City of Portland," May 1986, 0458-01, A02001001, PARC; Metropolitan Human Relations Commission, untitled document dated June 4, 1984, Metropolitan Human Relations Commission Housing Committee Reports, Minutes and Correspondence, A2001-022, PARC.

51. New Horizons Fair Housing Task Force, "Fair Housing Strategy Plan for the City of Portland," May 1986, 0458-01, A02001-001, PARC; Janet Christ, “Housing Plan Sent to Council,"Oregonian, June 4, 1986, p. 45.

52. Dee Lane and Steve Mayes, "Consumers and State Misled," Oregonian, September 9, 1990, p. A1; Housing Scams, 00-015 in PARC.

53. Dee Lane, "Major Lenders Aid Decline of NE Portland,"Oregonian, September 10, 990 , p. A1;

54. Lane, "Major Lenders Aid Decline of NE Portland"; Dave Hogan, "Jury Finds Dominion Capital Owners Guilty," Oregonian, March 8, 1996, p. A1; Dee Lane, "Neighborhood Activists Blame Blight on Lenders," Oregonian, September 11, 1990; Margie Boule, "A Home of Their Own", Oregonian December 17, 1991, P. O nd State Misled," Oregonian, September 9 , 